\title{
Comparación analítica de dos consolidantes comerciales aplicados en areniscas eocenas de monumentos de los siglos XVI y XIX en San Sebastián (norte de España)
}

\section{An analytical comparison of two commercial consolidating products applied to eocene sandstones from 16th and 19th century monuments in San Sebastián, northern Spain}

\author{
F. GARCÍA-GARMILLA" ; I. RODRÍGLEZ-MARIBONA ; M. CANO ; M. ZAIBIDE \\ J. A. IBÁNEZ-GÓMEZ ; E. OSA-CHANS' y S. GARÍN
}

\begin{abstract}
Universidad del País Vasco. Facultad de Ciencias. Dpto. Mineralogía y Petrología, Leioa (Vizcaya) LABEIN, Dpto. de Construcción y Materiales, Bilbao

Fecha de recepción: 10-VII-()1 TEUSA TECPROPASA EUSKADI, S.A., San Sebastián
\end{abstract}

RESUMEN

La conservación de los edificios del País Vasco construidos con areniscas del Eoceno es problemática porque este tipo de roca es relativamente inestable debido a su contenido variable en cemento carbonatado $(0-28 \%)$ y a la presencia de granos de feldespato potásico (1-13\%) disueltos tanto por procesos diagenéticos como ambientales. Hemos aplicado dos consolidantes comerciales: Sicof SM 296 (producto A) y Consistone $F S+A$ (producto $B$ ), ambos silicatos de etilo, sobre las areniscas de la Casa del Almirante Oquendo (siglo XVI) y el Palacio de la Diputación Foral de Gipuzkoa (siglo $X I X)$, ambos edificios en San Sebastián (Pais Vasco, norte de España). Los diferentes ensayos físicos y químicos junto con las observaciones al microscopio electrónico de barrido (SEM) revelan que el producto A es más eficiente para la consolidación de este tipo de areniscas, dado que penctra los primeros $8 \mathrm{~mm}$ de la roca, ocupa muy regularmente incluso los poros más pequeños y deja un cierto grado de porosidad remanente que permite la aireación de la roca. Por el contrario, el producto $B$ parece más adecuado para rocas con mayor tamaño de poro, dado que sólo penetra los primeros $3 \mathrm{~mm}$. Con ello, queda claro que la eficiencia de un consolidante comercial depende no sólo de su composición química, sino, en gran medida, de las caracteristicas texturales y litológicas de la roca sobre la que se va a aplicar:
SUMMARY

The conservation of buildings in the Basque Country made of Eocene sandstone is somewhat problematical, becalse this type of rock is relatively unstable. This instability is duc to the variable content of carbonate cement $(0-28 \%)$ and the presence of $K$-feldspar grains $(1-1.3 \%)$ which appear to have been dissolved by both diagenetic and environmental processes. We have compared the results of the application of two commercial consolidating products: Sicof SM 296 (product A) and Consistone FS+A (product B), both ethysilicates, on Eocene sandstones of the Oquendo Admiral House (16th century) and the Gipu-koa Provincial Government Palace (19th century), which are both located in the city of San Sebastian (Province of Gipuzkor. Bascuuc Country; Northern Spain). On the basis of different chemical and physical laboratory tests, together with Scanning Electron Microscopy (SEM) analysis, product A secms to be more efficient in consolidating such Eocene sandstone materials, since it penetrates into the first $8 \mathrm{~mm}$ of the rock, occupies very homogeneously even the smallest pore spaces and leaves a certain degree of remaining porosity which allows ventilation of the rock. In contrast, product $B$ seems to be more appropriate for larger pore-sized rocks, because it only penetrates into the first $3 \mathrm{~mm}$ of the Eocene sandstone samples clue to the thin pores of the 'itter. Our results demonstrate that the suitability of a commercial product depends not only on its own chemical composition, but also on the textural and lithological features of the rock material upon which it is to be applied.
PALABRAS ClaVE: areniscials, eoceno, edificios históricos, consolidación. silicatos de etilo
KEYWORDS: sandstones, eocene, historic buildings, consolidation, cthil-silicates 


\section{INTRODUCCIÓN}

En las últimas décadas se ha podido constatar por observación directa el rápido deterioro de las fachadas exteriores de varios edificios históricos del País Vasco, motivado principalmente por procesos de disolución que han afectado a los cementos naturales de la roca, $y$, en menor medida, por la colonización vegetal. Entre los edificios afectados, hemos estudiado dos: la Casa del Almirante Oquendo (CAO, siglo XVI) y el Palacio de la Diputación Foral de Gipuzkoa (PDFG, siglo XIX), ambos situados en el centro histórico de San Sebastián $(1-5)$.

La CAO (Figura 1), construida en 1580, tiene planta cuadrangular y es un excelente ejemplo de arquitectura civil renacentista. Su fachada principal (sur), construída con sillería de areniscas eocenas, está actualmente muy rebajada por la erosión. Por el contrario, las fachadas norte, este y oeste fueron construídas con una mampostería de areniscas más resistentes del Complejo Supraurgoniano (Cretácico medio).

Antes de su restauración, la CAO mostraba importantes lesiones. Las areniscas de su fachada principal estaban más rebajadas que los morteros de junteo entre ellas. Las laminaciones sedimentarias de la roca favorecieron una erosión según planos preferentes (Figura 2), de manera que, en general, habían desaparecido entre 5 y $10 \mathrm{~cm}$ de la parte más externa de la roca, llegando hasta $\operatorname{los} 20 \mathrm{~cm}$ en puntos concretos. Las arcadas superiores de las ventanas mostraban un aspecto «esponjoso». Para empeorar la situación, el canalón superior horizontal desaguaba directamente a ambos lados de la fachada.

El PDFG (Figura 3) data de 1885 y es un edificio representativo del clasicismo ecléctico. Resultó incendiado el 25 de diciembre de ese año, conservándose solamente las fachadas. El nuevo proyecto fue encargado a los arquitectos Aladrén y Morales de los Ríos en 1887.

El deterioro del PDFG era especialmente importante en las cornisas, balaustres y arcadas de la fachada meridional. No había un gran volumen de roca afectado, pero la inestabilidad de muchos elementos ornamentales constituía un peligro para los peatones. El edificio mostraba: a) descascarillamientos en finas lajas con precipitación de costras de ennegrecimiento bajo las cornisas, con frecuencia siguiendo la laminación paralela de la roca; b) erosión de los

\section{INTRODUCTION}

Over the last few decades, it has been worrying to observe directly the rapid course of the deterioration of the external façades of a number of historical buildings in the Basque Country. The causes for this can be found in dissolution processes which have affected the natural cements of the rock and, to a lesser extent, in regetal settling on the external surface of the rock. Such processes have affected many culturally important buildings such as the Oquendo Admiral House (OAH, I6th century) and the Gipuskea Provincial Government Palace (GPGP. I9th century), both in the historical centre of the city of San Sebasticin (l-5).

The OAH (Figure l), built in 1580, has a quadrangular shape and constitutes an excellent example of civil architecture during the Renaissance. Its main façade (southern) was constructed with Eocene sandstone masonry, which at present, show's signs of intense erosion. In contrast, the northern. eastern and western façades were made of a rubblework of much more resistant lithology, such as sandstone from the so-called Supraurgonian Complex (middle Cretaceous).

Before present-day restoration, the OAH exhibited several damage features. The sandstone of the main façade was so much eroded that the mortar between pieces resisted the weathering better than the stone! The sedimentary laminations of the rock faroured erosion along preferential planes (Figure 2). In general, up to 5-10 cm thickness of the rock was eliminated and in concrete places, this erosion reached up to 20 cm. The arches above the windows showed a sponge-like aspect. To make things worse. the upper horisontal gutter drained water to both sides of the main façade.

The GPGP (Figure 3) dates from 1885 and is a very fine example of eclectic classicism. The building suffered from a violent fire on the 25th of december of the same year, with only the façades surviving. A new. construction project was commissioned to the architects Aladrén and Morales de los Rios in 1887.

The deterioration of the GPGP is particularly pronounced in the cornices, banisters and relieving arches of the southern façade. The damage did not affect a large bolume of the building, but a number of ornaments became unstable, representing a conspicuous danger for pedestrians. The building suffered from: a) flake-off as thin stone labs with precipitation of blackened crusts below the cornices. This type of alteration was very frecuent, following the 
canecillos situados bajo la cornisa superior. La humedad progresó siguiendo las juntas entre sillares; c) disolución y formación de costras, sobre todo en los pilares troncocónicos de los balcones (Figura 4); y d) colonización vegetal bajo las cornisas superiores.

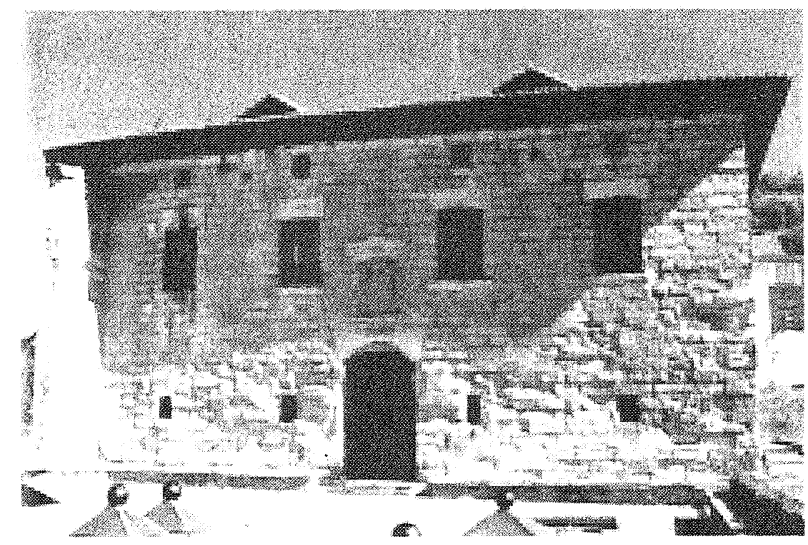

Figura 1.- Fachada principal de la Casa del Almirante Oquendo (CAO).

Figure 1.- The main façade of the Oquendo Admiral House (OAH).

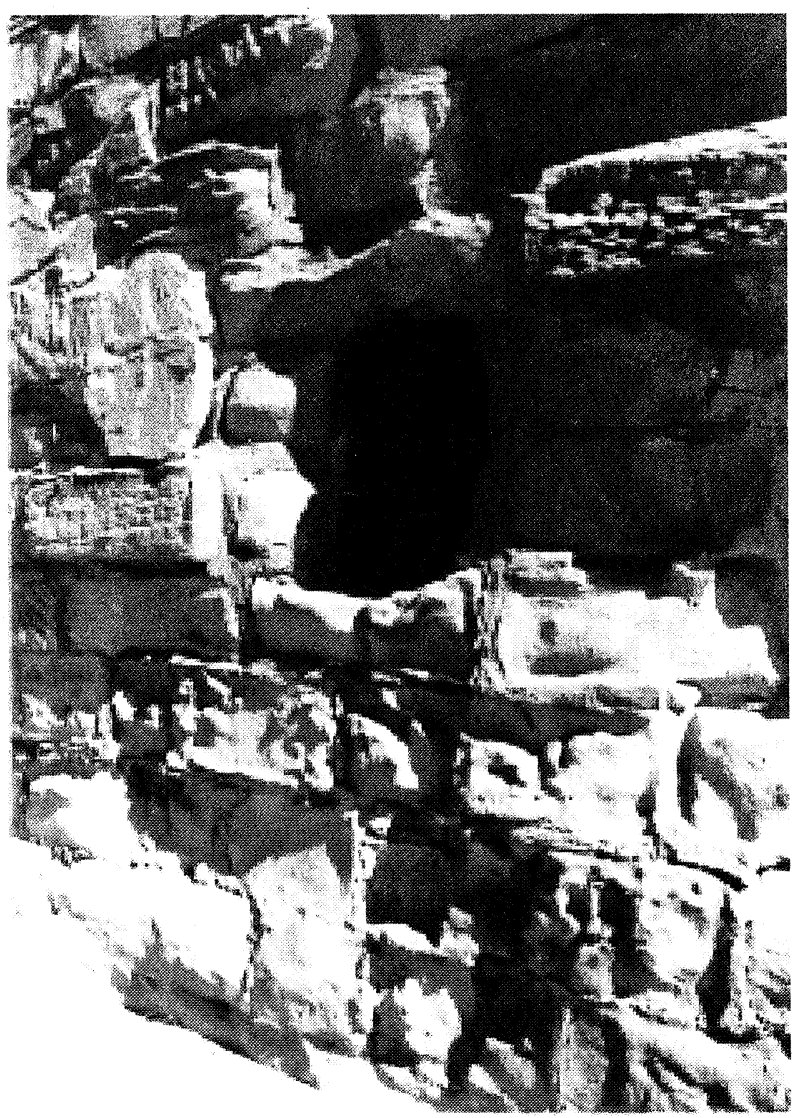

Figura 2.- Erosión diferencial de los sillares de la CAO

Figure 2.- Differential erosion of the ashlar stones of the OAH parallel lamination of the rock; b) erosion of the corbels below the upper cornices. The humidity progressed especially through the joints between stone blocks; c) dissolution and chip formation, particularly affecting the truncated conic pillars of the balconies (Figure 4); and d) vegetal settling, particularly below the upper cornices.

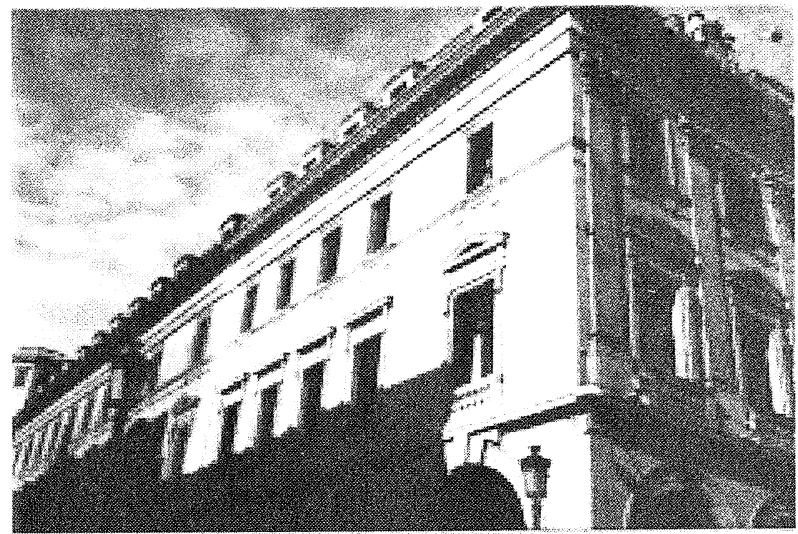

Figura 3.- Fachada principal del Palacio de la Diputación Foral de Gipuzkoa (PDFG)

Figure 3.- The main façade of the Gipu-koa Provincial Government Palace (GPGP).

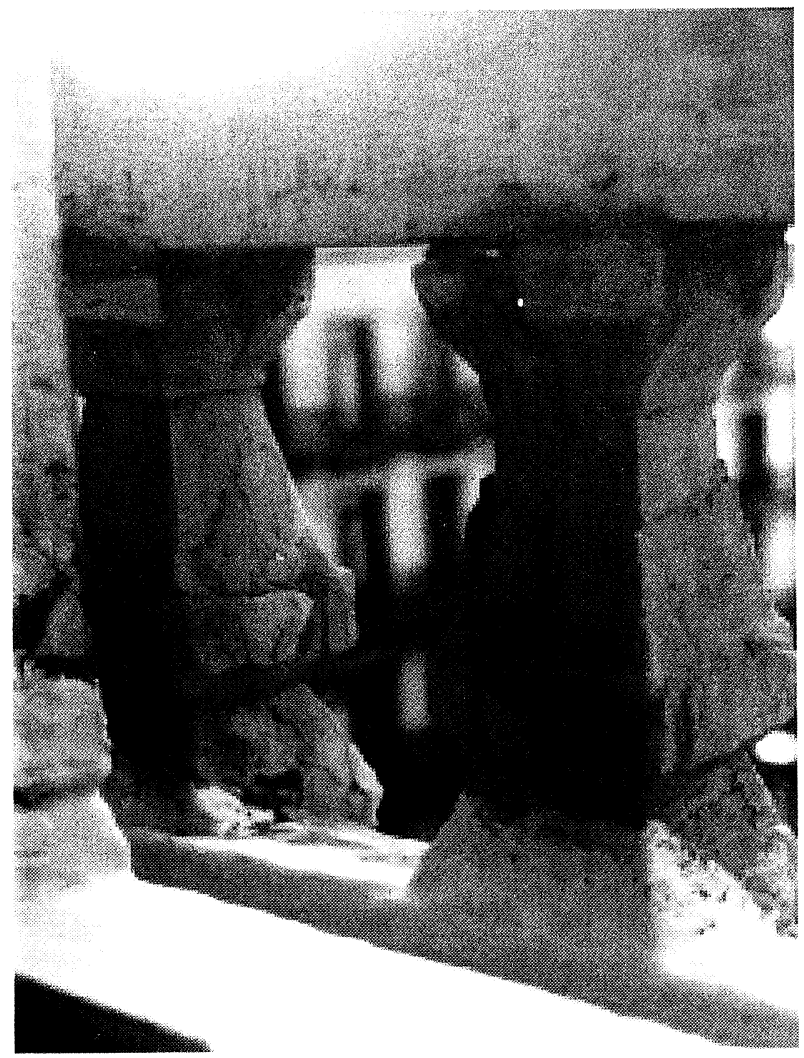

Figura 4.- Erosión y fracturación de los pilares de una balconada del PDFG.

Figure 4. Erosion and breakage of the balconv pillars of the (iPCP. 
La prevención del deterioro en el tipo de areniscas con que están construidos estos edificios se basa convencionalmente en el empleo de fungicidas, productos hidrorrepelentes y productos consolidantes. Estos últimos penetran en los poros de la roca y actúan como un cemento artificial. Aunque las areniscas dañadas tienen porosidades de un 25-30\%, la penetración del consolidante en la roca no es un proceso homogéneo, sino que depende de la composición y la morfología del producto una vez solidificado, así como del tamaño y grado de conexión (permeabilidad) de los poros de la arenisca. Es sabido que la porosidad y la permeabilidad pueden variar de manera significativa en areniscas aparentemente similares.

\section{METODOLOGÍA}

Los experimentos previos realizados con muestras de la $\mathrm{CAO}$, sobre las cuales se aplicaron seis consolidantes, permitieron seleccionar los dos más satisfactorios (Sicof SM 296 y Consistone FS+A). Ambos productos, que son silicatos de etilo, dieron tambien un buen resultado al aplicarlos en muestras del PDFG. Cada muestra de roca consistió en un conjunto de seis cubos de $5 \mathrm{~cm}$ de arista. Las muestras de rocas alteradas, $\sin$ alterar y tratadas con consolidante fueron sometidas a distintos tests de laboratorio: absorción de agua (UNE22182), succión de agua (UNE-67031), medidas de densidad y porosidad (ASTMD 440484) y pérdida en peso después de 9,14 y 20 ciclos de cristalización de sales (PE.MC-15E).

Los consolidantes se aplicaron a las muestras por el sistema de capilaridad y por todas las caras del cubo mediante una brocha en tres capas sucesivas, con una diferencia de cinco minutos entre cada aplicación. Se utilizó este procedimiento por ser el más similar al que luego se ejecutaría en la obra.

La profundidad de penetración de los consolidantes se midió al tercer día de su aplicación, antes de que perdieran sus propiedades hidrorrepelentes. Se estimó mediante el ensayo de la gota de agua, consistente en verter gotas sucesivas sobre un testigo de la roca tratada, cortado a lo largo de la dirección de penetración, y medir el punto en el cual las gotas pasaban de descansar sobre la superficie de la roca a ser absorbidas por ésta. En otros casos, la observación visual de las secciones fue suficiente, dado el color más oscuro que adquiría la roca impregnada de consolidante. El grado de humedad de las muestras fue estimado con un Protimeter Digital Mini (Neurtek) en los laboratorios de LABEIN. El porcentaje de porosidad y la distribución por tamaños medios de poro fueron determinados con un orosímetro de $\mathrm{Hg}$
The prevention of the deterioration of the type of sandstone of which these wo buildings were constructed, is conventionally based on the use of fungicides, waterproof products and consolidating products. The latter penetrate into the pore spaces of the rock and act as an artificial cement. Although the examination of damaged sandstones reveals porosities of up to 25-30\%, the penetration of consolidating products into the rock is not a homogeneous process. It depends on both the composition and morphology of the consolidating product once solidified, as well as on the size and connection (permeability) of the sandstone pores. It is known that porosity and permeability can vary enormously in apparently similar sandstones.

\section{METHODOLOGY}

Previous experiments on samples of rock from the $O A H$, in which six consolidating products were tested, permitted the selection of two suitable products (Sicof SM 296 and Consistone FS+A). Both products are ethyl-silicates, and also behaved satisfactorily when applied to the GPGP sandstone samples. Each rock sample consisted on a battery of six rock cubes $5 \times 5 \times 5$ $\mathrm{cm}$ in size. Unaltered (weakly eroded), altered (intensely eroded) and treated rock samples were subjected to different laboratory tests including: water absorption (UNE-22182), water suction (UNE-67031), density and porosity measurements (ASTMD 4404-84) and rock weight loss after 9, 14 and 20 crystallization cycles (PE.MC-15E).

The consolidating products were applied by a capillarity system upon the six faces of the cubesamples. The operation was repeated three times with an interval of five minutes between each application. This experimental procedure was chosen because of its similarity to that employed on the building façades.

The depth of penetration of consolidating products was measured the third day after their application, and before the loss of their waterproof properties. The water-drop method was employed, consisting of several drops dumped onto the surface of a consolidated rock-core, cut from outside to inside along the way of penetration. The point at which the drops left to rest on the rock surface and passed to be absorbed, marks the depth of penetration. In other cases, a simple visual examination was satisfactory, since rock impregnated with consolidating product is darker in colour. The degree of humidity of the rock samples was estimated using a Protimeter Digital Mini (Neurtek) in the LABEIN laboratories. The percentage of porosity and the distribution of the mean pore sizes was determined with a Poresizer $9400 \mathrm{Hg}$-porosimeter 
Poresizer 9400 (Micromeritics). La presión empleada fue de $207 \mathrm{MPa}$, con un rango de medida de 0.006 a $360 \mu \mathrm{m}$.

Los análisis de roca total por difracción de rayos $\mathrm{X}$ permitieron estimar la afinidad química entre la roca $y$ los productos consolidantes, así como determinar los minerales producidos por la alteración diagenética de granos como el feldespato potásico. Los análisis fueron realizados con un difractómetro automático Philips en el Departamento de Mineralogía y Petrología de la Universidad del País Vasco. Los difractogramas fueron obtenidos a ángulos $2 \theta$ entre $2^{\circ}$ y $70^{\circ}$, con un ángulo de salto de $0,02^{\circ}$ y un tiempo de 1 segundo por salto.

Las muestras de roca fueron examinadas con el microscopio electrónico de barrido Jeol JSM-6400 de la Facultad de Ciencias de la Universidad del País Vasco, así como con un microscopio petrográfico Olympus BH2. La microscopía electrónica de barrido (SEM) permitió visualizar tres aspectos: a) la textura de la roca de cantera sin alterar; b) el estado de la roca alterada en la fachada del edificio; y c) la textura del consolidante ya polimerizado y su relación textural con los poros y granos de la roca. Catorce muestras de la CAO y doce del PDFG fueron recubiertas con unapelícula de oro en condiciones de vacío $\left(3 \times 10^{-2}\right.$ $\mathrm{mBar}$ ) durante un tiempo comprendido entre 3 minutos, 20 segundos y 4 minutos, con una corriente de rociado de $15 \mathrm{~mA}$. El potencial empleado fue de $17-20 \mathrm{kV}$ y las distancias de trabajo variaron entre 7 y $14 \mathrm{~mm}$. Diversos rasgos texturales y composicionales de las muestras de roca fueron observados con el microscopio de luz transmitida.

\section{RASGOS DE LAS ARENISCAS PREVIOS A LA APLICACIÓN DE LOS PRODUCTOS CONSOLIDANTES}

Las areniscas empleadas en la construcción de la fachada sur de la CAO tienen una composición arcósica según la clasificación de Pettijohn et al. (1987) (6), con cemento de cuarzo, aunque la calcita espática puede llegar hasta el $28 \%$ en volumen de la roca. Su porosidad varía entre 4 y $11 \%$, si bien puede alcanzar el $25-30 \%$ en las rocas más alteradas. El tamaño de grano y la selección por tamaños de grano son más variables que en las muestras del PDFG. La Tabla 1 resume la composición y características texturales de las areniscas de la CAO.

Las areniscas del PDFG son igualmente subarcosas relativamente enriquecidas en glauconita (hasta un $8 \%$ ). Su composición mineralógica es menos variada que las de la CAO y su tamaño de grano y selección
(Micromeritics). The pressure employed was up to 207 $M P a$, with a measurement range from 0.006 to 360 $\mu m$.

Whole rock analyses by $X$-ray diffraction can be used to determine the chemical affinities between rocks and consolidating products, as well as to determine the minerals produced by diagenetic alteration of such grains as K-feldspar. Such analyses were carried out with a Philips automatic powder diffractometer in the $X$-ray laboratory of the Mineralogy and Petrology Department of the Basque Country University. Diffractograms were scanned from $2^{\circ}$ to $70^{\circ} 2 \theta$ with a $0.02^{\circ} 2 \theta$ step angle and 1 sec per step.

A JEOL JSM-6400 electronic microscope at the Science Faculty of the Basque Country University, as well as an Olympus BH 2 transmitted-light microscope were also employed in these studies. Scanning Electron Microscopy (SEM) was employed in order to study three aspects: a) the texture of the unaltered quarryrock; $b$ ) the condition of altered rock from the building façade; and c) the texture of the consolidating product and its textural relationship to the pores and grains of the rock. Fourteen $O A H$ rock samples and twelve GPGP samples were covered with a gold film under vacuum conditions $\left(3 \times 10^{-2} \mathrm{mBar}\right)$ for $3 \mathrm{~min} 20 \mathrm{sec}$ to 4 min with a sputtering current of $15 \mathrm{~mA}$. The potential employed was 17-20 kV and the work distances varied from 7 to $14 \mathrm{~mm}$. Textural and compositional determinations of the same samples were performed with transmitted-light microscopy.

\section{SANDSTONE CHARACTERISTICS BEFORE THE APPLICATION OF CONSOLIDATING PRODUCTS}

The sandstones employed for the construction of the southern façade of the OAH have an arkosic composition following the classification of Pettijohn et al. (1987) (6), their natural cements being quartz, although sparry calcite may occasionally reach up to $28 \%$ of the rock volume. Porosity varies from 4 to $11 \%$, but it can reach up to $25-30 \%$ in the most altered rocks. Grain size and sorting are more variable than in the samples of the GPGP. Table I summarizes the composition and textural characteristics of the $\mathrm{OAH}$ sandstones.

The GPGP" sandstones are also subarkoses which are relatively enriched in glauconite (up to $8 \%$ ) as an accessory mineral. Their mineral composition is less varied than that of the OAH samples. Their grain size 
por tamaños permanecen más o menos constantes. La Tabla 2 muestra la composición y características texturales de las areniscas del PDFG.

Observadas al SEM, las areniscas alteradas de la CAO muestran rasgos indicativos de disolución intragranular que afecta fundamentalmente a granos de feldespato potásico, junto con una fuerte disolución del cemento que da lugar a una importante porosidad intergranular (Figura 5a). Por este motivo la roca adquiere un aspecto esponjoso y experimenta una evidente pérdida de peso. La Figura 5b muestra minerales de la arcilla residuales procedentes de alteración controlada por los planos de exfoliación dentro de un grano de feldespato potásico. El resto del grano fue completamente disuelto. Las observaciones al SEM de las muestras del PDFG muestran crecimientos de cuarzo diagenético (Figura 5c) y disolución diagenética que afecta a los granos detríticos de feldespato potásico (Figura 5d).

Estas observaciones permiten afirmar que las areniscas eocenas utilizadas en la construcción de ambos edificios poseen una porosidad intragranular asociada a procesos diagenéticos, incrementada posteriormente con una porosidad intergranular causada sobre todo por la disolución del cemento natural debida a la meteorización ambiental. and sorting lalues are more or less constant. Table 2 shous the composition and textural characteristics of the GPGP sandstones.

Under SEM, the altered sandstones of the OAH exhibit features indicative of intragranular dissolution which affects mainly the K-feldspar grains, together with a strong cement dissolution which produces a high intergranular porosity (Figure 5 a). For this reason the rock acquires a spongy-like aspect and suffers from significant weight loss. The Figure $5 b$ show's remnant clay minerals which originated from an alteration controlled by the foliation planes into a K-feldspar grain. The rest of the grain was completely dissolved.

SEM observations of GPGP rock samples revealed several quart: diagenetic overgrowths (Figure 5c) and diagenetic dissolution affecting $K$-feldspar detrital grains (Figure 5d).

On the basis of these observations, we can conclude that the sandstones from both buildings suffer from intragranular porosity associated with diagenetic processes, followed by intergranular porosity largely caused by natural cement dissolution provoked by environmental weathering.

\section{TABLA I/TABLE I}

Composición y textura de las areniscas de la CAO (Q: granos de cuarzo, Plag: granos de plagioclasa, FdK. granos de feldespato potásico, Fr. fragmentos de roca, Min. Acc.: minerales accesorios, $\phi$ : diámetro medio de grano)

(Composition and texture of the OAH sandstone samples (Q: quart-grains, Plag: plagioclase grains, FaK: potasiumfeldspar grains, Fr: rock fragments, Min. Acc.: accessory minerals, $\phi$ : mean grain diameter))

\begin{tabular}{|c|c|c|c|c|c|c|c|}
\hline $\begin{array}{l}\text { Q monocrist. } \\
\text { Monocryst Q } \\
24-76\end{array}$ & $\begin{array}{l}Q \text { policrist. } \\
\text { Policryst } Q \\
1-t\end{array}$ & $\begin{array}{l}\text { Plag. } \\
\text { Plag } \\
0.5-2\end{array}$ & $\begin{array}{l}\text { FdK } \\
\text { FdK } \\
1-1.3\end{array}$ & $\begin{array}{l}\text { Fr. metamórficos } \\
\text { Metamorphic Fr } \\
1-3\end{array}$ & $\begin{array}{l}\text { Fr. chert } \\
\text { Chert Fr } \\
\text { l-6 }\end{array}$ & $\begin{array}{l}\text { Fr volcinicos } \\
\text { Volcanic Fr } \\
\text { ()-1 }\end{array}$ & $\begin{array}{l}\text { Fr sedimentarios } \\
\text { Sedimentary Fr } \\
0.5-25\end{array}$ \\
\hline $\begin{array}{l}\text { Fr. carbón } \\
\text { Coal } 1 \text { ir } \\
\text { ()-(1).5 }\end{array}$ & $\begin{array}{l}\text { Min. Acc. } \\
\text { Acc. Min. } \\
2-8\end{array}$ & $\begin{array}{l}\text { Fósiles } \\
\text { Fossils } \\
\text { ()-t }\end{array}$ & $\begin{array}{l}\text { Matriz } \\
\text { Mattrix } \\
3-6\end{array}$ & $\begin{array}{l}\text { Cemento } \\
\text { Cement } \\
3-6(Q) \\
0.5-1 \text { (FdK) } \\
0.5-1 \text { (óxidos Ie) } \\
\text { (Feoxides) } \\
\text { ()-28 (calcita) } \\
\text { (calcite) }\end{array}$ & $\begin{array}{l}0(\mathrm{~mm}) \\
0(\mathrm{~mm}) \\
0.15-1.05 \\
\\
\quad \text { (resultat } \\
\text { (resul }\end{array}$ & $\begin{array}{l}\text { Sorting (Powers) } \\
\text { Sorting (Powers) } \\
0 .+3-0.73 \\
\\
\text { en porcentajo en ic } \\
\text { xpressed in volume }\end{array}$ & $\begin{array}{l}\text { Porosidad } \\
\text { Porosity } \\
\text { t-11 (roca no allerada) } \\
\text { (umaltered rock) } \\
25-30 \text { (rocal allerada) } \\
\text { (altered rock) } \\
\text { nen de lat roca total) } \\
\text { of the whole rock) }\end{array}$ \\
\hline
\end{tabular}

TABLA 2/TABLE 2

Composición y textura de las areniscas del PDFG (Q: granos de cuarzo, Plag: granos de plagioclasa, FdK. granos de feldespato potásico, Fr. fragmentos de roca, Min. Acc.: minerales accesorios, $\phi$ : diámetro medio de grano)

(Composition and texture of the GPGP sandstone samples (Q: quart: grains, Plag: plagioclase grains, FaK: potasium-feldspar grains, Fr: rock fragments, Min. Acc.: accessory minerals, $\phi:$ mean grain diameter))

\begin{tabular}{|c|c|c|c|c|c|c|c|}
\hline $\begin{array}{l}\text { (2) monocrist. } \\
\text { Monocryst Q } \\
56-64\end{array}$ & $\begin{array}{l}\text { Q policrist. } \\
\text { Policryst Q } \\
1-2\end{array}$ & $\begin{array}{l}\text { Plag. } \\
\text { Playg } \\
1-3\end{array}$ & $\begin{array}{l}F d K \\
\text { FdK } \\
6-9)\end{array}$ & $\begin{array}{l}\text { Fr. metamorticos } \\
\text { Metamorphic Fr } \\
1-3\end{array}$ & $\begin{array}{l}\text { Fr. chert } \\
\text { Chert Fr } \\
\text { (). } 5-2\end{array}$ & $\begin{array}{l}\mathrm{Fr} \text { volciánicos } \\
\text { Volcunic Fr }\end{array}$ & $\begin{array}{l}\text { Fr. sedimentarion } \\
\text { Sedimentary Fr } \\
\text { l-t }\end{array}$ \\
\hline $\begin{array}{l}\text { Fr.carbón } \\
\text { Coil tri }\end{array}$ & $\begin{array}{l}\text { Min. Ace } \\
\text { Acc. Min. } \\
1(1)-12\end{array}$ & $\begin{array}{l}\text { Fósiles } \\
\text { Fossils }\end{array}$ & $\mid \begin{array}{l}\text { Mattrif } \\
\text { Mattrix } \\
+-9\end{array}$ & 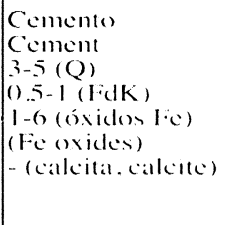 & $\begin{array}{l}O(m m) \\
O(m m) \\
0.15-0.25\end{array}$ & 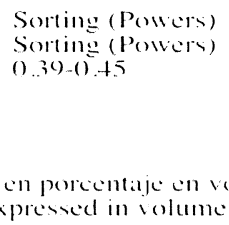 & 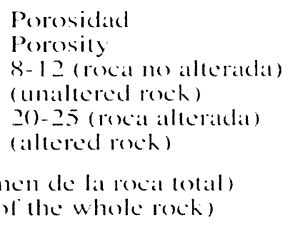 \\
\hline
\end{tabular}



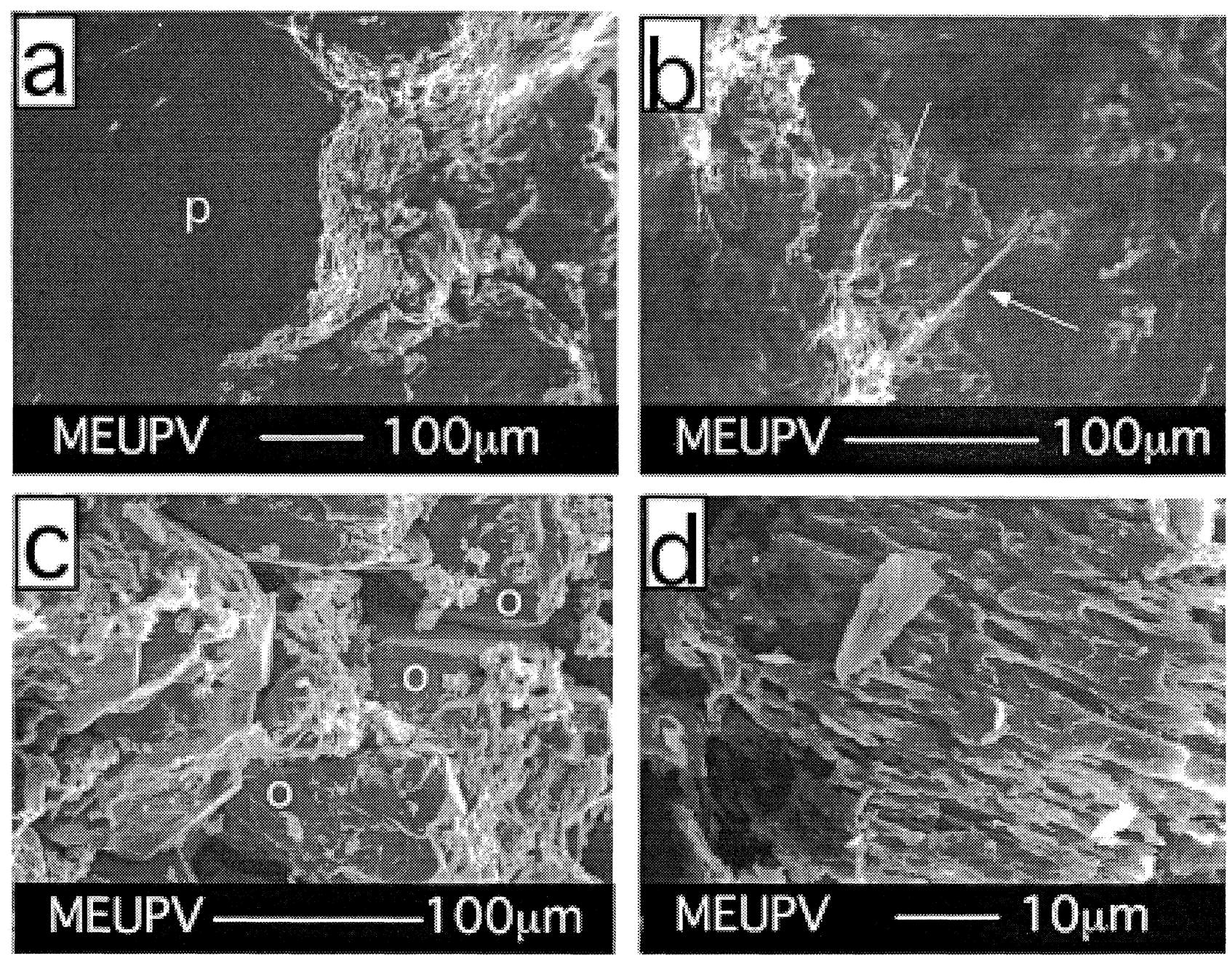

Figura 5.- Imágenes de SEM de muestras no consolidadas del CAO (a,b) y del PDFG (c,d): a) Arenisca «esponjosa» con porosidad intragranular (p) generada por disolución; b) Disolución de un grano de feldespato potásico con relictos de minerales de la arcilla (señalados con flechas); c) Crecimientos de cuarzo autigénico (o) sobre granos de cuarzo detrítico; d) Disolución diagenética de un grano de feldespato potásico.

Figure 5.- SEM images of $(a, b)$ OAH and (c,d) GPGP unconsolidated rock samples: a) The sandstone becomes «spongy» with the subsequent creation of intragranular porosity by dissolution (p); b) K-feldspar grain dissolution leaving remains of shale platelets (arrowed), c) Quartz. overgrowths (o) upon detrital quartz grains; d) Diagenetic dissolution of a K-feldspar grain.

\section{RESULTADOS DE DIFRACCIÓN DE RAYOS X}

Los difractogramas realizados sobre muestras de la $\mathrm{CAO}$ revelan que las areniscas eocenas se componen de cuarzo (Qz), moscovita (Mcv), feldespato alcalino (Fd), illita y a veces calcita (Ca) (Figura 6a). Por su parte, las areniscas del PDFG constan de cuarzo, feldespato alcalino, illita y ocasionalmente caolinita y clorita, junto con trazas de yeso (Figura 6b). La abundancia relativa de caolinita es inversamente proporcional a la de cuarzo, lo que es indicativo de la meteorización de los granos de feldespato. La composición de este tipo de rocas es compatible con la aplicación potencial de productos silíceos amorfos (Figuras 7 a y $7 \mathrm{~b}$ ) porque la arenisca original es muy rica en sílice $(7,8)$.

\section{X-RAY DIFFRACTION RESULTS}

The measured diffractograms of OAH samples show that the Eocene sandstone is mainly made up of quartz $(Q z)$, muscovite (Mcv), alkali feldspar $(F d)$, illite and sometimes calcite (Ca) (Figure 6a). The GPGP sandstone is composed of quartz, alkali feldspar, illite and occasional kaolinite and chlorite, together with traces of gypsum (Figure $6 \mathrm{~b}$ ). The relative abundance of kaolinite is inversely proportional to that of feldspar, which is indicative of the weathering of feldspar grains. The composition of these rocks is compatible with the potential application of amorphous siliceous products (Figures $7 a$ and $7 b$ ) because the original sandstone is clearly silica-enriched $(7,8)$. 



Figura 6.- a) Espectro de rayos $\mathrm{X}$ de una muestra de arenisca de la CAO (Qz: cuarzo, Ca: calcita, Mcv: moscovita, Ab: albita); b) Espectro de rayos $\mathrm{X}$ de una muestra de arenisca del PDFG (Qz: cuarzo, $\mathrm{Ph}$ : filosilicatos, Fd: feldespato alcalino, Gp: yeso).

Figure 6. - a) X-ray spectrum of an OAH sandstone sample (Qz: quartz, Ca: calcite, Mcv: muscovite, Ab: albite); $b) X$-ray spectrum of a GPGP sandstone sample (Qz: quartz, $P$ : phyllosilicates, $F d$ : alkali-feldspar, Gp: gypsum).
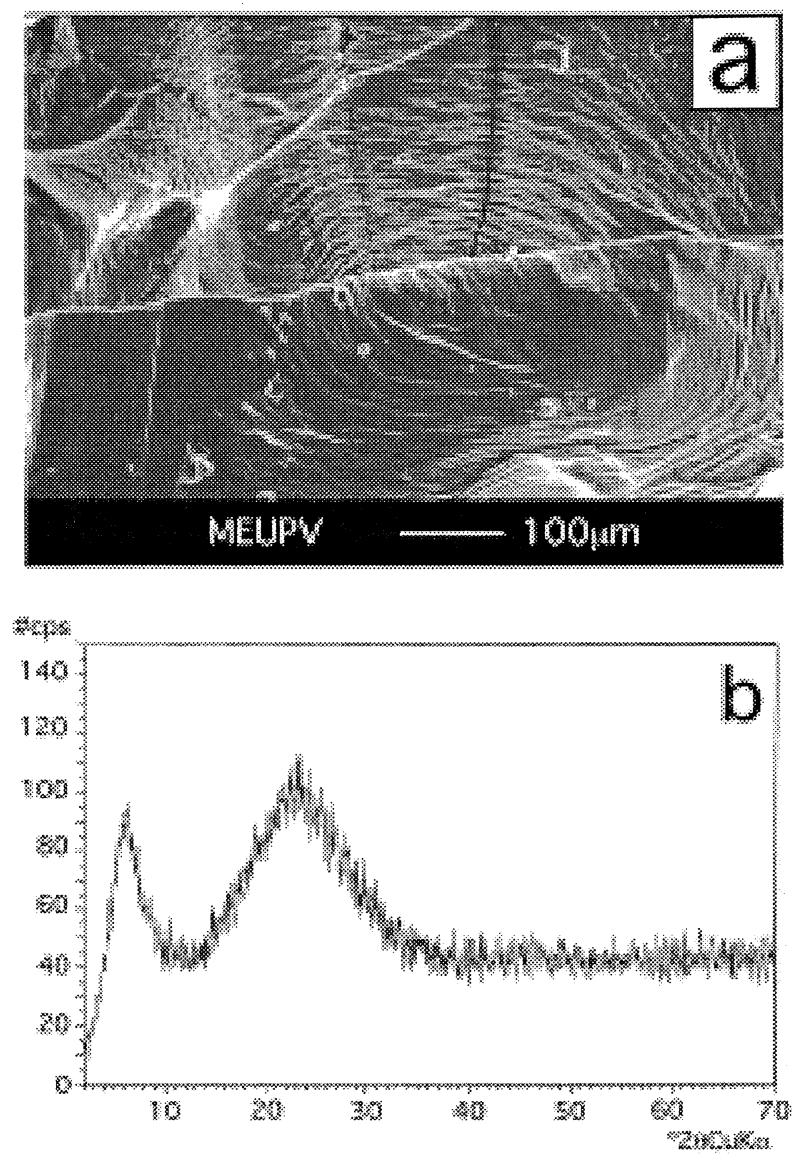

Figura 7.- a) Aspecto al SEM del producto consolidante A semisolidificado. Se comporta como un gel con microfracturas concéntricas y radiales producidas por la pérdida del disolvente por evaporación; b) Difractograma del producto consolidante A en el que se constata su naturaleza amorfa.

Figure 7.- a) The semi-solidified consolidating product A, seen under SEM. Its behaviour is like a gel showing both concentric and radial open microfractures produced by the evaporative loss of the solvent. b) Diffractogram of consolidating product A clearly showing its amorphous nature.

\section{LABORATORY TESTS AND ROCK RESPONSES TO THE APPLIED CONSOLIDATING PRODUCTS}

\section{APLICACIÓN DE LOS PRODUCTOS CONSOLIDANTES}

Los resultados de los diferentes ensayos de laboratorio se muestran en las Tablas 3 (CAO) y 4 (PDFG). Como los pilares de los balcones del PDFG se encontraban muy deteriorados, se consideró conveniente presentar los resultados de laboratorio de rocas tanto alteradas como no alteradas en la Tabla 4 para posteriores comparaciones. A nuestro juicio, los resultados más ilustrativos son la profundidad de penetración del consolidante en la roca y la pérdida de volumen de roca después de 20 ciclos de cristalización de sales. La
The results of the different laboratory tests are summarized in Table 3 (OAH samples) and Table 4 (GPGP samples). As the balcony pillars of the GPGP showed a high degree of alteration, we considered it convenient to include the laboratory results of both altered and unaltered rocks in Table 4 for further comparisons. Perhaps the most definitive tests are the depth of penetration of the consolidating product and the rock volume lost after 20 salt crystallization cycles. The reduction in rock porosity is slightly greater when 
Resultados de los ensayos de laboratorio realizados sobre muestras de la CAO

(Results of laboratory tests of OAH sandstone samples)

\begin{tabular}{|c|c|}
\hline $\begin{array}{l}\text { Absorción de agua/Water absorption }(\%) \\
\text { Succión de agua/Water suction }\left(\mathrm{gr} / \mathrm{cm}^{2} / \mathrm{min}\right) \\
\text { Densidad/Density }\left(\mathrm{gr} / \mathrm{cm}^{3}\right) \\
\text { Porosidad/Porosity }(\%) \\
\text { Diámetro medio de poro/Pore mean diameter }(\mathrm{mm}) \\
\text { Cristalización de sales }(\% \text { de pérdida en peso) } / \text { Salt crystallization } \\
(9 \text { ciclos } / 14 \text { ciclos } / 20 \text { ciclos) }(9 \text { cycles } / 14 \text { cycles } / 20 \text { cycles })\end{array}$ & $\begin{array}{l}\text { Roca alterada (Altered rock) } \\
7.59 \\
0.109 \\
2.025 \\
24.68 \\
0.09 \\
\text { (weight-loss in \%) } \\
39.24 / 85.39 / 96.89\end{array}$ \\
\hline $\begin{array}{l}\text { Absorción de agua/Water absorption }(\%) \\
\text { Succión de agua/Water suction }\left(\mathrm{gr} / \mathrm{cm}^{2} / \mathrm{min}\right) \\
\text { Densidad/Density }\left(\mathrm{gr} / \mathrm{cm}^{3}\right) \\
\text { Porosidad/Porosity }(\%) \\
\text { Diámetro medio de poro/Pore mean diameter }(\mathrm{mm}) \\
\text { Cristalización de sales }(\% \text { de pérdida en peso) } / \mathrm{Salt} \text { crystallization } \\
\text { (9 ciclos } / 14 \text { ciclos } / 20 \text { ciclos) }(9 \mathrm{cycles} / 14 \mathrm{cycles} / 20 \text { cycles }) \\
\text { Profundidad de penetración/Penetration depth }(\mathrm{mm})\end{array}$ & $\begin{array}{l}\text { producto A (After application of product A) } \\
0.77 \\
0.0018 \\
2.111 \\
20.18 \\
0.09 \\
(\text { weight-loss in \%) } \\
0.9 / 0.47 / 0.5 \\
6-8\end{array}$ \\
\hline $\begin{array}{l}\text { Absorción de agua/Water absorption }(\%) \\
\text { Succión de agua/Water suction }\left(\mathrm{gr} / \mathrm{cm}^{2} / \mathrm{min}\right) \\
\text { Densidad/Density }\left(\mathrm{gr} / \mathrm{cm}^{3}\right) \\
\text { Porosidad/Porosity }(\%) \\
\text { Diámetro medio de poro/Pore mean diameter }(\mathrm{mm}) \\
\text { Cristalización de sales }(\% \text { de pérdida en peso) } / \mathrm{Salt} \text { crystallization } \\
\text { (9 ciclos/14 ciclos } / 20 \text { ciclos) }(9 \text { cycles/14 cycles } / 20 \text { cycles) } \\
\text { Profundidad de penetración/Penetration depth }(\mathrm{mm})\end{array}$ & $\begin{array}{l}\text { producto B (After application of product B) } \\
0.71 \\
0.0038 \\
2.104 \\
22.27 \\
0.091 \\
(\text { weight-loss in \%) } \\
0.031 / 0.89 / 1.86 \\
2.4\end{array}$ \\
\hline
\end{tabular}

\section{TABLA 4/TABLE 4}

Resultados de los ensayos de laboratorio realizados sobre muestras del PDFG.. Los dos productos A y B se aplicaron a la roca alterada

(Results of laboratory tests of GPGP sandstone samples. Both product $A$ and $B$ were applied to altered rock)

Absorción de agua/Water absorption (\%)

Succión de agua/Water suction $\left(\mathrm{gr} / \mathrm{cm}^{2} / \mathrm{min}\right)$

Densidad/Density $\left(\mathrm{gr} / \mathrm{cm}^{3}\right)$

Porosidad/Porosity (\%)

Diámetro medio de poro/Pore mean diameter $(\mathrm{mm})$

Cristalización de sales (\% de pérdida en peso) / Salt crystallization (weight-loss in \%)

( 9 ciclos $/ 14$ ciclos $/ 20$ ciclos) ( 9 cycles $/ 14$ cycles $/ 20$ cycles)

Tras la aplicación del producto A

Absorción de agua/Water absorption (\%)

Succión de agua/Water suction $\left(\mathrm{gr} / \mathrm{cm}^{2} / \mathrm{min}\right)$

Densidad/Density $\left(\mathrm{gr} / \mathrm{cm}^{3}\right)$

Porosidad/Porosity $(\%)$

Diámetro medio de poro/Pore mean diameter $(\mathrm{mm})(\mathrm{mm})$

Cristalización de sales (\% de pérdida en peso) / Salt crystallization (weight-loss in \%)
(9 ciclos/14 ciclos $/ 20$ ciclos) (9 cycles $/ 14$ cycles/20 cycles) $0 / 0 / 0$

Profundidad de penetración/Penetration depth $(\mathrm{mm})$
(After application of product A)

$$
\begin{aligned}
& 0.81 \\
& 0.0068 \\
& 2.01 \\
& 22.1 \\
& 0.084 \\
& \text { (weight } \\
& 0 / 0 / 0 \\
& 7-8
\end{aligned}
$$

0.0068

Roca alterada (Altered rock)
5.98
0.092
2.03
23.7
0.090
$13.23 / 18.93 / 30.61$

Tras la aplicación del producto B

(After application of product B)

5.22

0.0004

2.011

22.23

0.094

$8.87 / 10.57 /$ broken-up sample 2-3

(resultados despues de una triple aplicación de consolidantes con una humedad del 9-15\% en la superficie de la roca) (results after the triple application of the consolidant product at a humidity of $9-15 \%$ in the rock surface)

reducción en la porosidad de la roca es algo mayor en las muestras tratadas con el producto A. En efecto, en las muestras de la $\mathrm{CAO}$, el producto $\mathrm{A}$ reduce la porosidad en un $4,5 \%$, mientras el $\mathrm{B}$ lo hace solo en el $2,4 \%$; en el caso del PDFG, el producto A reduce la samples were treated with product A compared to product $B$ (for $O A H$ samples, product $A$ reduces porosity by $4.5 \%$ while product $B$ induces a reduction of $2.4 \%$; for GPGP samples, product $A$ reduces porosity by $1.6 \%$ vs. $1.5 \%$ for product $B$ ). This fact 
porosidad en un $1,6 \%$, en tanto que el B lo hace en un $1.5 \%$. Esto sugiere que el producto A penetra mejor que el $\mathrm{B}$, dejando todavía un cierto grado de porosidad que favorece la aireación de la roca (9).

Los ensayos de ciclos sucesivos de cristalización de sales se cuentan entre los más agresivos que se pueden practicar en la roca. Las muestras sin tratar experimentaron pérdidas de peso (con relación al peso inicial) entre un $16.26 \%$ (PDFG, roca sin alterar), un $30,61 \%$ (PDFG, roca alterada) y un $96,89 \%$ (CAO), despues de 20 ciclos. La enorme pérdida de peso de la roca alterada de la CAO $(96,89 \%)$ (Tabla 3 ) es explicable dado el fuerte grado de alteración que ya previamente había sufrido la roca como consecuencia de la cristalización de sales marinas ambientales y el proceso de biodeterioro por hongos que la afectaban. Dicha muestra quedó prácticamente convertida en polvo tras los 20 ciclos de cristalización de sales.

El tratamiento con el producto A hizo la roca más resistente a la fracturación que el producto $\mathrm{B}$ tras el mismo número de ciclos. Con el primero, la pérdida en peso fue de solo $0.5 \%$ (CAO) e incluso nula (PDFG), mientras el B llevó a reducciones en peso del 1.86\% (CAO) y no pudo evitar la fracturación de las probetas del PDFG. De aquí concluímos que el producto A arroja un mejor resultado que el $\mathrm{B}$ en el caso concreto de las areniscas terciarias de ambos edificios.

\section{RASGOS DE LAS ARENISCAS POSTERIORES A LA APLICACIÓN DE LOS PRODUCTOS CONSOLIDANTES}

Desde el punto de vista textural, el tamaño de poro de la roca y el tamaño de molécula del producto consolidante una vez solidificado parecen estar claramente relacionados. Ambos consolidantes A y B se basan en un polímero orgánico de silicato de etilo cuyos disolventes son fundamentalmente alcoholes que progresivamente se pierden por evaporación. La Figura $7 \mathrm{a}$ es una imagen de SEM del producto A semisolidificado. Consiste en una sustancia gelatinosa que presenta fracturas tanto concéntricas como radiales producidas por la retracción asociada a la pérdida de los disolventes. El tamaño de poro de las areniscas, pequeño y muy uniforme, resulta probablemente más adecuado para el producto $\mathrm{A}$, en tanto que el $\mathrm{B}$ ofrecería mejores resultados en areniscas (u otros tipos de roca) con un tamaño de poro mayor.

Las observaciones al SEM muestran que la distribución de los productos consolidantes en el interior de la roca no es homogénea. Pueden reconocerse diferentes morfologías de solidificación, aunque, en algunas suggests that product $A$ enters the rock better than product $B$, but still leaves a certain degree of porosity which favours the ventilation of the rock (9).

Salt crystallization tests are among the more aggressive tests which can be performed upon sandstone samples. In fact, the untreated samples suffered from weight-losses (relative to original weights) ranging from $16.26 \%$ (GPGP, unaltered rock) to $30.61 \%$ (GPGP, altered rock) to $96.89 \%$ (OAH) after 20 salt crystallization cycles. The enormous weight-loss of the CAO altered rock (96.89\%) (Table 3) can be explained as the result of the intense degree of previously experienced alteration owing to environmental marine salt crystallization and biodeterioration by fungi. The last sample became pulverized after 20 salt crystallization cycles.

Treatment with product A led the rock to become very resistant to breaking-down after the same number of cycles; rock weight loss was only $0.5 \%(O A H)$ or even nil $(G P G P)$, whereas product $B$ exhibited a more irregular behaviour, reducing rock weight loss to $1.86 \%(O A H)$, and it did not prevent the breakingdown of the GPGP rock cubes. Overall, it can be deduced that consolidating product A behaves better than product $B$ in the rock material of both buildings.

\section{SANDSTONE CHARACTERISTICS AFTER THE APPLICATION OF CONSOLIDATING PRODUCTS}

From a textural point of view, the pore size of the rock and the molecular size of the consolidating product once it has solidified, seem to be clearly related. Both consolidating products $A$ and $B$ are based on an organic polymer of ethyl-silicate and their solvents are mainly alcohols which progressively vanish by evaporation. Figure $7 a$ is a SEM image of semisolidified product $A$. This product consists of a gelatinous substance in which both concentric and radial microfractures produced by retraction, associated with the removal of alcohol solvents, can be observed. The small and relatively homogeneous pore size of the sandstones probably underlies the better behaviour of product $A$. In contrast, product B seems to be more appropriate for sandstones (or other types of rocks) having greater pore sizes.

SEM observations revealed that the distribution of the consolidating products in the rock is not homogeneous. Different solidification morphologies can be recognized, although in some rock areas, the presence 
zonas, es difícil detectar la presencia de estos productos dada la baja porosidad que tiene la roca cuando la matriz y/o el cemento rellena los poros de mayor tamaño. El producto A se muestra como una «pasta» homogénea que ocluye la porosidad intergranular y contacta íntimamente con los bordes de los granos de la trama. En algunos poros, presenta el aspecto de una masa amorfa que engloba las laminillas de los minerales de la arcilla y está fracturado según líneas concoidales (Figura 8a) of these products cannot be easily observed due to the lack of porosity owing to the presence of abundant matrix andlor cement, in the major pore spaces. Product A appears as a homogeneous "paste» which slightly occludes the intergranular porosity and intimately contacts the border of the framework grains. In some pores we can see product $A$ as an amorphous mass which includes clay platelets and breaks in conchoidal fracture lines (Figure 8a).
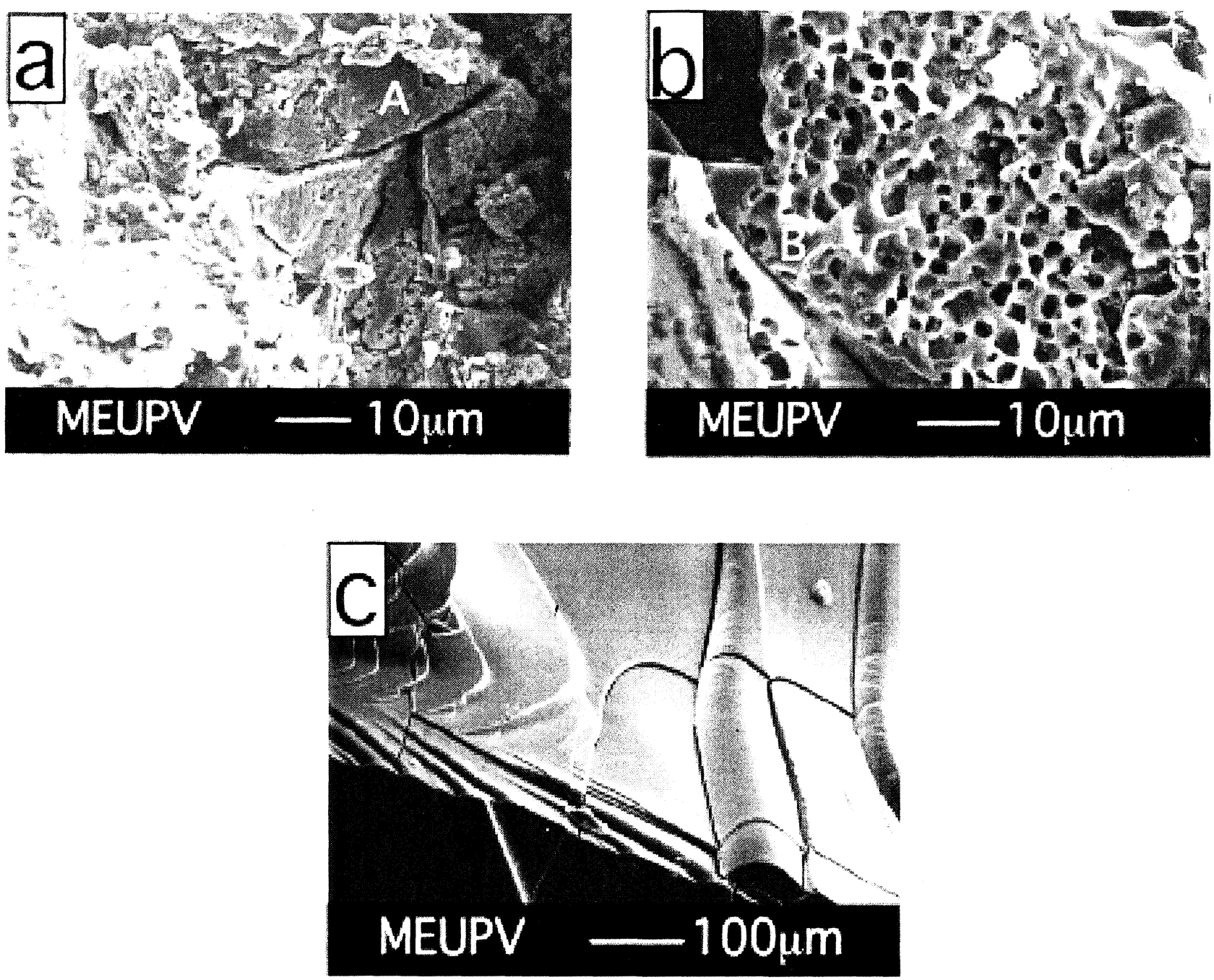

Figura 8.- Imágenes de SEM de rocas tratadas con los productos consolidantes: a) Aspecto masivo del producto A (A) que engloba laminillas de minerales de la arcilla y presenta microfracturas concoidales producidas como resultado de la evaporación del disolvente (muestra de la CAO): b) Aspecto de la masa vacuolar del producto B (B) que recubre los granos detríticos de una muestra de areniscal del PDFG; c) Aspecto del producto A directamente solidificado a partir de una muestra líquida. La sustancia es amorfa y carece de porosidad.

Figure 8. SEM images of consolidated rock and solidified consolidating products: a) A mass of product A (A) including minute clay mineral platelets and showing conchoidal microfiactures as a result of eraporation of solvent (OAH sample): b) An aspect of the ruggy mass of product B (B) covering the detrital grains of a sandstone from GPCP: a) The product A as directly solidificed from a liquid sample. The substance is amorphous, lacking porosits. 
Por otra parte. el producto $B$ aparece en forma de una masa trabecular muy porosa, a veces incapaz de ligar la matriz con los granos de la trama. En otros puntos, se concentra siguiendo los bordes de los granos, pero manteniendo un cierto grado de porosidad (Figura 8b). Podemos asumir que. en general. la efectividad de un cemento natural depende del grado en el cual rodea a los granos de la roca. Por lo tanto, desde un punto de vista textural. si los consolidantes juegan un papel similar al de los cementos naturales, el producto $\mathrm{A}$ puede considerarse tambien como un mejor consolidante para las areniscas del Eoceno de Gipuzkoa. Sin embargo, hay que advertir que los productos consolidantes normalmente aparecen dispersos en pequeñas cantidades en los poros de la roca. y que sus concentraciones principales tienen lugar lógicamente en los poros de mayor tamaño. donde sus estilos de solidificación están ligados a «zonas de estancamient()». dado que son sustancias amorfas cuya morfología final debe estar relacionada con las fuerzas de capilaridad existentes en el interior de los poros. Ello se inficre al comparar las texturas de estos productos cuando solidifican directamente a partir de una muestra líquida (Figura 8c) y cuando lo hacen en el interior de los poros de la roca.

\section{CONCIUSIONES}

La clección del consolidante más adecuado para un tipo concreto de arenisca es decisiva en la restauración de edificios. Para obtener los mejores resultados necesitamos estudiar con detalle las propiedades físicas y químicas de la roca en el afloramiento natural, en estado de degradación y despues de su tratamiento con productos de restauración.

Los análisis de rayos $X$ revelan que existe una clara compatibilidad química entre las areniscas eocenas, ricas en sílice, y la composición de ambos productos consolidantes A (Sicof SM 296) y B (Consistone FS $+A$ ), basados en silicatos de etilo. Los resultados de rayos $X$ tambien muestran que muchos granos de feldespato potásico se alteraron diagenéticamente a caolinita (Ph en la Figura 6). Este proceso, cuando sc generaliza. conlleva una reducción en el grado de consolidación de la roca con la subsiguiente entrada de aguas meteóricas en ella, lo que causa una disolución destructiva a gran escala.

Los ensayos de laboratorio han demostrado que el tratamiento de la roca con el producto A le proporciona una mejor resistencia a los ciclos de cristalización de sales que tratada con el B. Trass una triple aplicación. se observa (que el producto $A$ penetra en la roca $40.5 \mathrm{~mm}$ más que el B. dejando una porosidad sólo un $1-4 \%$ inferior a la de la roca en estado degradado. I:llo
On the other hand, product B appears as a highlyporous trabecular mass, which is sometimes unable to link the matrix and the framework grain. In other regions of the rock, product $B$ concentrates along the borders of the grains. but maintains a high degree of porosity (Figure (b)). It is generally assumed that the effectiveness of a natural cement depends on the degree to which it surrounds the grains of the corresponding rock. Thus, from a textural point of riew; if consolidating products are to play a role similar to those of natural cements, product $A$ can be considered to be a better consolidating product for the Eocene sandstones of Gipuzko buildings.

Nevertheless it must be said that the consolidating products normally appear disperse in minor amounts in the pore spaces of the rock, and that their main concentrations in the larger pores exhibit solidification styles probably linked to "stagnant sones" in which the amorphous substances acquire a morphology related to capillarity forces. This can be deduced from a comparison between the textures of these products when they solidify from an isolated liquid sample (Figure $8 \mathrm{c}$ ) and when they solidify in the pores of the rock.

\section{CONCLUSIONS}

The choice of an appropriate consolidating product for a particular type of sandstone is crucial for the effective restoration of buildings. For optimal results. the chemical and physical properties of the rock in the natural outcrop, in a degraded state and after treatment with consolidating products, need to be accurately studiced.

$X$-ray analysis reveals a clear chemical compatibility between the silica-enriched Eocene sandstones and the composition of the consolidating products A I Sicof SM 296 and $B$ (Consistone FS+A) (ethyl-silicates). The Xray results also reveal that a number of $K$-feldspar grains suffered from diagenetic alteration to kaslinite (Ph in Figure 6). This process, if generalised can lead to a reduction in the degree of consolidation of the rock and the subsecuent facility of meteoric waters to enter the rock. causing destructive dissolution on a largescale.

Laboratory tests revealed that treatment with product A provides better resistance to salt revstallization areles than with product B. We also observed that after a triple application, product A penetrates the rock 4 or 5 mm more than product $B$. while still leaving only I $4 \%$ less rock porosity than in the altered rock. This 
sugiere que el producto A recubre las paredes de los poros en forma de una fina película permitiendo una buena aireación de la roca.

La presencia de los consolidantes en la roca no siempre es fácil de observar al SEM como podría suponerse inicialmente. En efecto, donde la porosidad de la roca está ocluída, se inhibe la penetración del producto. Por consiguiente, es probable que algunas partes concretas de la roca puedan escapar a la influencia del producto. Sin embargo, parece claro que otras partes han debido tener un grado de consolidación natural inicialmente aceptable en función de la litificación de la matriz arcillosa y/o la precipitación diagenética de cementos de cuarzo.

El producto A aparece como una «pasta» compacta que rellena los poros y contacta íntimamente con los bordes de los granos detríticos de la arenisca. Por el contrario, el producto $\mathrm{B}$, una vez solidificado, es de textura más porosa y aparentemente de comportamiento más rígido que el producto A. Aparece en forma de una masa vacuolar que presenta puntos de separación o despegue con las superficies externas de los granos, dejando aún bastante porosidad remanente. La comparación entre ambos estilos texturales sugiere que el producto $B$ puede tener un mayor tamaño molecular que el $\mathrm{A}$, por lo que resultaría más adecuado para rocas con un tamaño de poro mayor que el de las areniscas del Eoceno objeto de este estudio.

Aunque ambos consolidantes han sido probados exhaustivamente antes de su comercialización, es obvio que su resultado final depende de las características físicas de cada tipo de arenisca sobre la cual se apliquen. Ello supone que la selección de un tipo específico de producto de restauración debe hacerse una vez que las muestras de roca a tratar hayan sido examinadas a través de los diferentes ensayos de laboratorio y sus texturas observadas al SEM y con microscopía óptica convencional.

\section{AGRADECIMIENTOS}

Este trabajo de investigación ha sido financiado por el Gobierno Vasco a través de los Proyectos de Investigación UE 97/23 y UE 98/3. Expresamos nuestro agradecimiento a la Dra. $\mathrm{M}^{\mathrm{a}}$ Luisa de Nó por su ayuda en las observaciones de microscopía electrónica y a la agencia ACTS (acts@euskalnet.net) por la revisión del texto en inglés. suggests that product A covers the pore walls as a very thin film allowing good ventilation of the rock.

The presence of consolidating product in the rock is not easy to observe by SEM imaging as was expected. This fact suggests that occluded rock porosity inhibits the penetration of the product. Consequently, it is probable that some minor volumes of the rock may escape the consolidating influence of these products. Nevertheless, it is highly likely that some parts of the rock may have previously had an acceptable degree of natural cansolidation owing to the inherent lithification of the argillaceous matrix andior the precipitation of quart: cement overgrowths.

Product A appears as a compact "paste» which infills the pores and makes intimate contact with the borders of the detrital grains of the sandstone. In contrast, product $B$, once solidified, is more porous and apparently stiffer in behaviour than product $A$. It appears as a vacuolar mass which shows "separation points» from the grain surfaces and still leaves a large degree of remaining porosity. A comparison between both textural styles suggests that product $B$ may have a larger molecular size than product $A$. Consequently, product $B$ could be more appropriate for rocks having pore sizes greater than those of the Eocene sandstones which we have studied.

The results of this study indicate that although both consolidating products have been accurately tested before their commercialization, the final performance of these products strongly depends on the inherent physical properties of the particular type of sandstone to which they will be applied. It can be concluded that the choice of a particular consolidating product for rock restoration should be made once rock samples have been examined using laboratory analytical techniques and their textures analysed using both SEM and conventional microscopy.

\section{ACKNOWLEDGEMENTS}

This research was financially supported by the Basque Government through Research Projects UE 97/23 and UE 98/3. We wish to express our thanks to Dr M"Luisa de No for her help during SEM observations and to the agencyACTS(acts@euskalnet.net)for improving the English of this manuscript.

\section{BIBLIOGRAFÍA}

(1) F. García-Garmilla. Proyecto de Restauración de la Casa del Almirante Oquendo (San Sebastián). Estudio Petrológico. p. 196. Universidad del País Vasco/Gobierno Vasco, 1998. 
(2) F. García-Garmilla. Proyecto de Restauración del Palacio de la Excma. Diputación Foral de Gipuzkoa (San Sebastián). Estudio Petrológico. p. 156. Universidad del País Vasco/Gobierno Vasco, 1999.

(3) F. García-Garmilla, S. Garín, J.A. Ibáñez-Gómez, I. Rodríguez-Maribona. M. Zalbide: Caracterización mediante microscopía electrónica de barrido del deterioro de las areniscas de edificios históricos y su tratamiento con consolidantes: la Casa del Almirante Okendo (s.XVI) (San Sebastián, País Vasco). XIX Reunión Bienal de la Sociedad Española de Microscopía Electrónica (SEME). Abstracts Book (1999), pp. 429-430.

(4) F. García-Garmilla, I. Rodríguez-Maribona, M. Cano. J.A. Ibáñez-Gómez, M. Zalbide, S. Garín, E. Osa-Chans: Aplicaciones de la Microscopía Electrónica de Barrido al estudio del deterioro y la restauración de edificios históricos: la Casa de Oquendo (s.XVI) y el Palacio de la Diputación (s.XIX) (San Sebastián, País Vasco). Geogaceta, Vol. 28 (2000). pp. 59-62.

(5) I. Rodríguez-Maribona, M. Zalbide, F. García-Garmilla, J.A. Ibáñez-Gómez, S. Garín: Estudio de conservación del material pétreo de la Casa de Cultura del Almirante Oquendo en San Sebastián. Materiales de Construcción, Vol. 49, n”255 (1999), pp. 1930 .

(6) F.J. Pettijohn, P.E. Potter. R. Siever. Sand and Sandstone. p. 553, Springer Verlag. New York, 1987.

(7) J.A. Ibáñez-Gómez. Proyecto de Restauración de la Casa del Almirante Okendo (San Sebastián). Estudio mineralógico por difracción de rayos X. p. 42. Universidad del País Vasco/Gobierno Vasco, 1998.

(8) J.A. Ibáñez-Gómez. Proyecto de Restauración del Palacio de la Excma. Diputación Foral de Gipuzkoa (San Sebastián). Estudio mineralógico por difracción de rayos X. p. 30. Universidad del País Vasco/Gobierno Vasco, 1999.

(9) M. Cano, I. Rodríguez-Maribona, S. Espina. Optimización de la metodología de consolidación para la restauración de edificios históricos en función de la microestructura del sistema material base/consolidante. p. 42. LABEIN, 1999. 


\section{FE DE ERRATAS}

Debido a diferentes motivos, las figuras de la página 12 no tienen la calidad deseada. A continuación se reproducen con la calidad adecuada
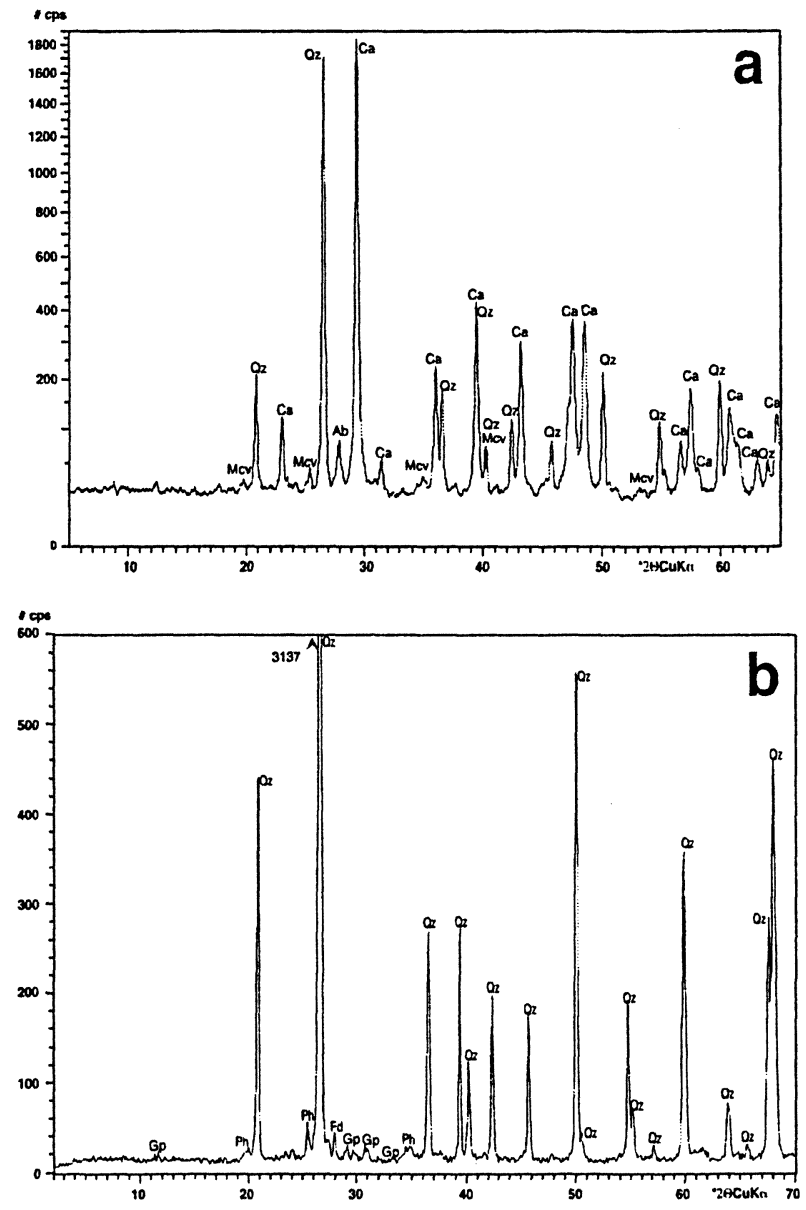

Figura 6.- a) Espectro de rayos $X$ de una muestra de arenisca de la CAO (Qz: cuarzo, Ca: calcita, Mcv: moscovita, Ab: albita); b) Espectro de rayos $\mathrm{X}$ de una muestra de arenisca del PDFG (Qz: cuarzo, Ph: filosilicatos, Fd: feldespato alcalino, Gp: yeso).

Figure 6. - a) X-ray spectrum of an $O A H$ sandstone sample ( $Q z$ : quartz, Ca: calcite, Mcv: muscovite, Ab: albite); b) X-ray spectrum of a GPGP sandstone sample (Qz: quartz, Ph: phyllosilicates, Fd: alkali-feldspar, Gp: gypsum).
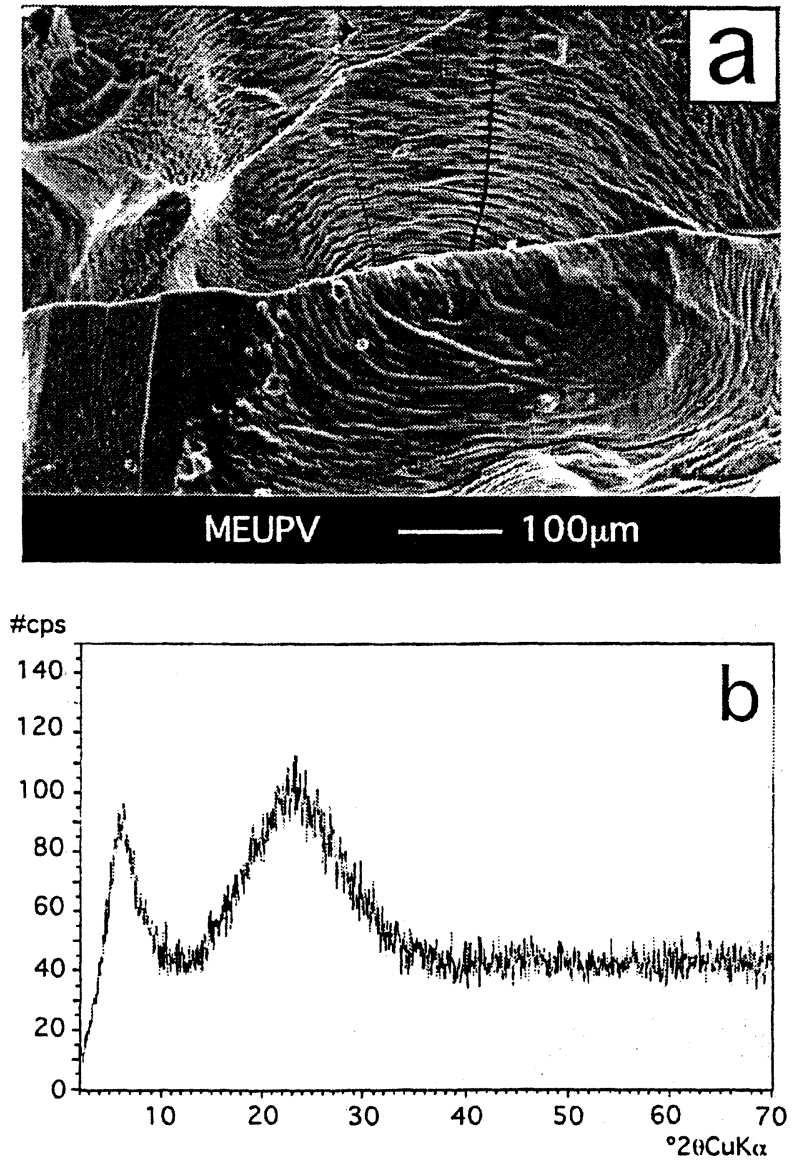

Figura 7.- a) Aspecto al SEM del producto consolidante A semisolidificado. Se comporta como un gel con microfracturas concéntricas y radiales producidas por la pérdida del disolvente por evaporación; b) Difractograma del producto consolidante A en el que se constata su naturaleza amorfa.

Figure 7.- a) The semi-solidified consolidating product A, seen under SEM. Its behaviour is like a gel showing both concentric and radial open microfractures produced by the evaporative loss of the solvent. b) Diffractogram of consolidating product A clearly showing its amorphous nature. 